\title{
The Institutionalization of Mobility: Well-being and Social Hierarchies in Central Asian Translocal Livelihoods
}

\section{Philipp Schröder \& Manja Stephan-Emmrich}

To cite this article: Philipp Schröder \& Manja Stephan-Emmrich (2016) The Institutionalization of Mobility: Well-being and Social Hierarchies in Central Asian Translocal Livelihoods, Mobilities, 11:3, 420-443, DOI: 10.1080/17450101.2014.984939

To link to this article: https://doi.org/10.1080/17450101.2014.984939

\section{( ) 2014 The Author(s). Published by Taylor \& Francis}

\section{曲 Published online: 16 Dec 2014.}

Submit your article to this journal ๘

Џلll Article views: 3811

Q View related articles $₫$

View Crossmark data ¿

Citing articles: 12 View citing articles 4 


\title{
The Institutionalization of Mobility: Well-being and Social Hierarchies in Central Asian Translocal Livelihoods
}

\author{
PHILIPP SCHRÖDER \& MANJA STEPHAN-EMMRICH \\ Institute for Asian and African Studies, Humboldt Universität zu Berlin, Berlin, Germany
}

\begin{abstract}
In the wider scientific debate, post-Soviet Central Asia has been primarily known for the question in what ways this region currently experiences a 'New Great Game' of geostrategy and resource-competition. In contrast to that, ethnographic research on the various cross-border mobilities, networks and identifications of non-elite actors from countries such as Kyrgyzstan or Tajikistan has set off only recently. Proposing a conceptual approach based on 'translocality' and 'livelihood', this article presents in-depth case studies which explore how Central Asians engage in 'business-making', 'evolve' their Muslim piety, transgress rural-urban boundaries and experience ethnic marginalization in between 'home' and cities in Russia, China or Egypt. We show how mobility is institutionalized, i.e. how within these 'translocal livelihoods' geographic relocations do not only combine with social mobility, but that assessments on personal well-being and the orientation on cultural norms also draw on somebody's particular position within social hierarchies of gender and generation.
\end{abstract}

KEY WORDS: Translocal, Livelihood, Ethnography, Central Asia, Russia, China, Egypt

\section{Introduction}

Since the collapse of the Soviet Union in 1991, the empire's former 'southern periphery' in Central Asia ${ }^{1}$ has developed into a vibrant hub for the movement of people, commodities and ideas between the 'international West', the 'Muslim South' and the neighbouring (super)powers China and Russia.

Essential aspects of this current situation are Russia's claim to maintain politicoeconomic leverage in its former 'back yard', the liberal West's ambitions to spread principles of democracy and equal rights in a largely autocratic part of the globe, as well as China's surge for expanding its commodity trade across the borders of its post-Soviet neighbours. While all of these large-scale players also share instant aspirations for accessing the region's vital energy resources, eventually they manoeuvre in a sociocultural environment of 'newly independent' Republics, where in face of

Correspondence Address: Philipp Schröder, Humboldt Universität zu Berlin, Institute for Asian and African Studies, Invalidenstrasse 118, 10115 Berlin, Germany. Email: pschroeder@asa.hu-berlin.de in any medium, provided the original work is properly cited. The moral rights of the named author(s) have been asserted. 
varying forms of (ethnic) nationalism and Islamic influences from South Asia, Turkey or the Arab world, their prospect for success remains uncertain. Reaching back to an era before the 70-plus-year Soviet/Socialist interlude, some commentators, emphasizing either the historical parallels or deviations of such regional interest constellations, discuss today's situation in terms of a 'New Great Game' or a 'New Silk Road' (e.g. Ahrari 2002; Cooley 2012; Edwards 2003; Karrar 2009; Mullerson 2007; Rashid 2000).

As regards these scientific efforts, whereas there are ample works that address the upper tier of geopolitical strategy, resource utilization and power lobbying in contemporary Central Asia, only few contributions track these larger trends 'down' to the micro-level of everyday life. There, however, the 'small games' of 'regular', non-elite Central Asians raise important questions about how exactly these are involved in various economic, social, cultural and religious exchanges that crisscross the borders within and beyond this region.

This situation again differs from other recent developments in the humanities, including social and cultural anthropology, where for quite some time now the creative participation of mobile actors in various global 'flows', 'transnational social fields' and 'transnational connections' has been occupying a prime spot on the research agenda (e.g. Appadurai 1996; Glick Schiller and Fouron 1999; Hannerz 1996). Related to this, there is another important line of research that focuses on the different pathways that such (im-)mobile actors take to integrate and manage their lives in their 'receiving' societies. This as well includes research on the multiple relations that reconnect them to their places of origin and the effects of this on the practices of (multiple) identity formation (e.g. Glick Schiller and Simsek-Caglar 2009; Nieswand 2011; Vertovec 2009).

In contrast to these established debates on the 'New Great Game' (in the field of international relations) and on 'transnationalism' (in anthropology and sociology), the first substantial ethnographic insights on phenomena such as 'transmigrants' (Basch, Glick Schiller, and Blanc 1994), 'long-distance nationalism' (Glick Schiller 2005) and diaspora networks from the context of post-Soviet Central Asia were published only recently. ${ }^{2}$ These pioneering studies primarily focus on the motivations of Central Asians to migrate, on the flow and utilization of remittances, or on the coping mechanisms of non-migrants 'left behind' (see e.g. Hegland 2010; Isabaeva 2011; Reeves 2012, 2011; Ruget and Usmanalieva 2008). Inevitably, at this early stage of research, significant issues of the Central Asians' transnational entanglements have remained unexplored. This even concerns such vital fields as education, religion, social integration and commodity trade.

The topics of ethnography's emerging attention for Central Asian transnationalism aside, it is noteworthy that this new strand of research has predominantly remained within the regional paradigm of post-Soviet studies (and, for example, investigates migration from Kyrgyzstan or Tajikistan to Russia). Therefore, in line with other approaches that are critical towards a narrow understanding of 'area studies' (e.g. Freitag and von Oppen 2010; Schetter 2012), we advocate a research perspective which centres on the ways that people, ideas and localities relate to one another in social practice, thereby creating contexts that may transgress conventional national, regional, scientific and other boundaries.

Starting from these observations, in the following paragraphs, we first outline a basic conceptual framework for researching the 'small (within the great) games' in Central Asia and beyond. This framework draws on the notions of 'translocality' 
and 'livelihoods'. In the main section of the article, we will then present four ethnographic cases, all of which illustrate certain features within the contemporary translocal livelihoods of mobile Central Asians, be these (1) business-making and social networking; (2) religious morality and global youth lifestyles; (3) rural-to-urban migration and education; or (4) cross-border marriage and ethnicity.

These case studies substantiate the argument for 'translocal livelihoods' as a conceptual tool, which enables us to consider linguistic and other cultural boundaries next to national borders, as well as to account for the intangibles of 'a good life' beyond material considerations. Furthermore, comparing these cases reveals how mobility is institutionalized, i.e. in what way locations matter to our mobile interlocutors depending on their respective positioning within hierarchies of gender and generation. Eventually, this leads to ambivalent assessments, in which the Central Asian 'home' is simultaneously experienced as a place of collective cultural pressures and of 'natural' belonging. At the other end, foreign or urban destinations such as Moscow, Bishkek, Cairo or Dushanbe are not unambiguously associated with social mobility and personal freedom, but pose the challenge to 'always be successful' and also may entail anxieties about ethnic exclusion.

\section{Translocality and Livelihood}

In a recent reassessment of 'multi-sited ethnography' (Coleman and von Hellermann 2011), about 15 years after Marcus' (1995) influential article on 'Ethnography in/of the World System', James Ferguson reflects on the question whether in our times of advanced global connectedness, anthropology would need a 'new kind of object to take the place of 'culture' and 'society' ... an object that would capture within itself the social and spatial relations that traverse our old, spatially defined objects?' (2011, 197-198).

Ferguson's take on this query is as simple as it is intriguing. Instead of continuing to draw on the notion of an 'object of study', he proposes that ethnography should be based on: first, a careful attention for the relations between the facts of its inquiry, and second, on the conceptualization of objects as practices. The first approach Ferguson $(2011,198)$ calls the (classic) 'method of contextualization', i.e. the way of 'making sense' by interconnecting ethnographic facts and by 'building webs of relations' among them (be these social, semiotic or discursive). The second approach, according to Ferguson $(2011,200)$, is to break down and transform - by ways of 'methodological reflection' - abstract objects of study into sets of (observable) practices, which then can be studied ethnographically.

As Ferguson is happy to admit himself, these are insights that anthropologists can be quite familiar with. Nevertheless, his thoughts remind us that not necessarily do our current times demand a cardinal epistemological turnaround, as even the largest scale 'global phenomena' eventually still occur and are dealt with by people in very particular localities. From this, we can see, on the one hand, that the potentially 'deterritorialized' and post-national state of modernity notwithstanding, 'localities still matter'. Ferguson's methodological remarks therefore are quite in line with Appadurai's $(1996,186)$ by now classic observation that all 'locality-producing activities' are 'context-generative', i.e. they are influenced by social and other practices within villages or other small communities, same as they are 'context-driven', meaning that any such community also has to respond and adapt 'to a material context wider than itself', such as that of a nation-state (see also Peleikis 2010). But, on 
the other hand, while tracking how the topics of their studies are constituted through their interlocutors' relations and practices, researchers - today more than some decades ago - may need to attend to multiple field sites with quite some distances and borders/boundaries (in)between them.

At that significant junction of space, mobility and the social, the term 'translocality' comes in. For one significant reason, in this article, we prefer to speak of 'translocal' instead of 'transnational' livelihoods. This is not because we would have learned these terms to be fundamentally different, as both of them have been applied to capture, for instance, the myriad ways how migrants are 'simultaneously incorporated' both in their society of origin and in that of their destination. ${ }^{3}$ In this regard, a notion such as that of the 'transnational social field' (Glick Schiller and Fouron 1999; Levitt and Glick Schiller 2004; Nieswand 2011) has proven indispensible for migration research in order to overcome the problematic paradigm of 'methodological nationalism', i.e. the misconception that 'the nation/state/society is the natural social and political form of the modern world' (Wimmer and Glick Schiller 2002, 301).

However, as Freitag and von Oppen $(2010,12)$ have rightly pointed out, the term translocal is less liable than the term transnational to draw attention to political units and their respective nation-state borders (regardless of whether from there on one aims to argue for the continued power of nation-states or against it; see Smith 2011). This observation is obviously true for historical case studies which focus on a period before nation-states emerged in Africa and other areas of the so-called 'global South' in the early twentieth century (e.g. Heintze 2010). But also the 'pluri-local social practices' (Pries 2001, 8) of migrants in the twenty-first century do transgress multiple boundaries. Among these, national borders are only one type, next to such rather informal separations as those between language codes, urban and rural areas, or other 'cultural spaces'. ${ }^{4}$ Ultimately, such a translocal perspective argues for no more than to remain open to the fact that, despite the refiguration of many places' social architecture and relational topologies on a transnational basis, 'the formation of migrant selfhood is usually more closely related to localities within nations than to nationstates'. (Conradson and McKay 2007, 169)

Furthermore, when speaking of 'translocality', there is a dialectic process to keep in mind between mobility and 'place-making', which Smith $(2011,181)$ describes as 'multiple emplacement or situatedness both here and there'. In case migrants express such simultaneous belonging to both their locations of origin and destination(s), analytically, this implies to look at various 'institutionalizations' of mobility, which may be based on social networks, religious and 'traditional' value systems, or ethnic and other identifications. Here, the geographic domain of placement and movement can relate with further research themes, such as the negotiation of emotions and moral economies alongside long-distance (financial) exchanges (McKay 2007; Velayutham and Wise 2005) or the complex of gossiping, social control and gender construction across continents or within Muslim spaces (Drotbohm 2010; Lachenmann 2010).

In our case, next to translocality, we perceive the notion of livelihood to be a complementary element within a relational and context-sensitive approach to everyday realities that are marked by various mobilities and institutionalizations. Susanne Thieme (2008), in what so far has been among the few articles on this topic referring to a Central Asian context, has suggested to connect 'transnational migration' and 'livelihood studies'. 5 In line with other recent approaches, such as that endorsed by the UK Department for International Development, Thieme $(2008,53)$ argues to 
move beyond an understanding that strictly reduces livelihood to the material, economic domain of the (rural) poor, but instead includes a variety of other 'social, human, financial, natural, and physical [forms of] capital' (see also Sorensen and Olwig 2002).

Although departing from a distinct focus on hunter-gatherers and as part of a more elaborate argument on the 'perception of the environment', Ingold (2000) makes a somewhat similar case for overcoming a too narrow understanding of livelihood. On his way to develop an ecological approach that focuses on how both non-humans and humans are continuously 'engaging' with their surroundings, Ingold $(2000,9)$ objects to the conventional division between livelihood - if reduced to mean only those (natural, material) resources that people can make a living from - and the notion of lifeworlds, which conventionally are understood to be 'imaginatively 'constructed', in myth, religion and ceremony'.

In her work on Kyrgyz migrants in between Moscow and their rural homes in Central Asia, Madeleine Reeves $(2009,2012)$ has developed similar thoughts, maintaining that our analysis should not to be constrained by a simple 'economic determinism', but should incorporate those rituals, morals and other intangibles that inextricably are part of any migration's microdynamics.

Already from such a cursory reading, we can deduce that expanding the perspective on livelihoods obliges a researcher to attend to a multitude of material and immaterial 'goods' of everyday livelihoods. Furthermore, this entails to take into account the interlocutors' alternative capacities for success and well-being, which may first and foremost be associated with family constellations, personal health, the natural environment or religious persuasions. Such effort corresponds to recent advancements towards an 'anthropology of well-being', which aims to combine an objective, measurable dimension - e.g. household income or the amount of remittances - with people's subjective evaluation of the their life situations, such as their emotional constellations (Mathews and Izquierdo 2009a).

In line with these considerations, we understand our contribution to be an ethnographic and conceptual complement to Thieme's (2008) rather general remarks on the theoretical link between transnational migration and livelihood studies. From the next section onward, we will present in-depth case studies on the livelihoods of several young Central Asians. These extend from Kyrgyzstan and Tajikistan to various locations outside that region, but also reflect the recent developments in our interlocutors' original home countries.

In that regard, both Kyrgyzstan, due to its 'revolutions' in 2005 and 2010, and Tajikistan, due to a civil war from 1992 to 1997, are states that have experienced significant political conflict and social instability. At the same time, their weak economic performance has resulted in massive labour migration and a strong dependency on remittances from abroad. Our case studies will refer to these processes, yet as well they provide links to a particular post-Soviet and regional context that is marked by the expansion of market capitalism and cross-border trade, by the emergence of new border regimes alongside ethnic nationalism, and by the internationalization of education and of Islamic belief and practice.

With a distinct focus on (extended) families and other personal networks, we certainly look at the smaller games of mobile actors within the 'New Great Game' that is currently playing out in Central Asia and along the 'New Silk Road'. In order to grasp the informal complexities of how individual aspirations, religious attitudes, ethnic and other ways of identification are negotiated within such small games, our 
article follows an ethnographic approach based on the qualitative methods of participant observation and informal (narrative) interviewing. The data presented in the upcoming case studies was collected during multiple long-term fieldwork trips in between 2006 and 2013, mainly to Tajikistan's capital Dushanbe, as well as to the cities of Bishkek and Osh in Kyrgyzstan.

\section{Aziz: From Osh to Moscow to Guangzhou - 'A Business in the Making'}

Aziz is a young Kyrgyz male in his 20s. He originates from the city of Osh in southern Kyrgyzstan, close to the border with Uzbekistan. Aside from his home region in Central Asia, Aziz's story will take us to the city of Moscow in Russia, as well as to Guangzhou in southern China. And while there would be many more important threads to follow in this case, our main focus will be on how a 'business in the making' relates with Aziz's interpersonal constellations, meaning the social ties within and beyond his kinship network.

Aziz claims that already at an early age, when he was about 17 years old, he had clearly known what would be best for him in terms of a successful future. At that time, in 2004, for a young Kyrgyz male, there were several opportunities that conventionally qualified to carry this label. For some, success would have meant to become a chinovnik and enter into the ranks of public office, for which in Kyrgyzstan's corrupt bureaucratic system the prime 'return of investment' usually comes in the form of bribes and business protection (Engvall 2011). As we will see in a later case study, other young people in Kyrgyzstan feel that their future rather lies in the vibrant sector of international, 'Western'-funded organizations, which aside from solid salaries also offer training programmes for continuing professional education.

And then, there would have been work migration. In Kyrgyzstan, the country's independence from the Soviet Union in 1991 brought far-reaching changes: most significantly a shock-therapy economic liberalization and the transition to a democratic-style political system. Initially, these changes triggered far-reaching internal migration from Kyrgyzstan's rural areas towards the cities. About a decade had passed, when around the year 2000, larger numbers of Kyrgyz migrants began seeking work opportunities abroad. For this, the prime destination turned out to be Russia, which due to a shared Soviet history and the widespread ability among Central Asians to speak Russian could be perceived as a 'familiar cultural space' (Laruelle 2007). Thus, the majority of Kyrgyz migrants first headed towards Moscow, St. Petersburg or other Russian cities in order to find work, mostly on construction sites or in low-skill service jobs (Reeves 2011).

In contrast to these predominant patterns, Aziz opted for a novel route. Following his high school graduation in Osh, he applied for a stipend to study Chinese language at a prestigious university in Moscow (which would then turn out cheaper for him than to study in China itself). Officially, this was with the aim to become a linguist and translator, yet for Aziz it was always obvious that Chinese will serve as the decisive skill to advance his future career as a trader.

In light of recent political and economic developments, Aziz's turn towards China seems obvious. Especially since both China (in 2001) and Kyrgyzstan (in 1998) joined the World Trade Organization (WTO), the Middle Kingdom's aspirations towards being the world's biggest goods producer (again) is clearly seen in small neighbouring Kyrgyzstan (Melet 1998; Tang 2000). Supported by low import tariffs, Chinese consumer products have come to dominate Kyrgyzstan's bazaars, making in 
particular the re-export business to regional non-WTO members, such as Uzbekistan, Kazakhstan and (until 2012) Russia, a lucrative opportunity within Kyrgyzstan's otherwise struggling economy. In this situation, following Chinese goods back to their manufacturing origins is a decision that in many other parts of the global economy has proven to be successful for establishing a middleman business with considerable profit margins.

Still, traders have remained a clear minority (5\%) among Kyrgyz work migrants in Russia. ${ }^{6}$ Historically, on top of the negative image that Soviet propaganda had painted of any kind of 'trader-speculator' (Humphrey 2002), many ethnic Kyrgyz frame this phenomenon within their pastoral nomadic heritage, thereby associating bazaar trade and business-making primarily with their Uzbek neighbours (as longtime sedentary urban dwellers). This notwithstanding, the focus of those Kyrgyz who have engaged in trade used to be on the Russian consumer market: be that in the past as importers of fruits, flowers and vegetables from the 'southern' peripheral republics to the Soviet Union's centre (Sahadeo 2011), or nowadays by bringing China-manufactured goods to Russian bazaars via Kyrgyzstan.

In contrast to that, Aziz envisions himself to be among the few Kyrgyz pioneers who deal with Chinese goods neither in Kyrgyzstan nor in Russia, but closer to the origin of the trade chain in southern China. And so, equipped with the necessary stipend and with some financial support from his parents, in 2006, Aziz moves to Moscow to begin his studies of Chinese language. Looking back, Aziz describes his years in Moscow as a 'full life', a busy time when he had to study hard and work on the side to make ends meet; but also this was a period for him when he could enjoy the 'freedom of a student's life' together with the new friends he made in the dormitory and elsewhere in the city. With these new contacts, in the course of time, Aziz creates a social environment that increases his everyday comfort level in Moscow and lessens his homesickness in between the one or two trips a year that he can make back to Kyrgyzstan.

Aside from the everyday moral and other support among these Moscow friends, it is his evolving network that Aziz, next to the Chinese language abilities, sees as an essential second pillar on his way to becoming a young entrepreneur. An example of this is Aziz's friendship with Bakyt, who is another young Kyrgyz male living in Moscow. Although Bakyt is not a student like Aziz, but 'only' works as a waiter in a café, the two establish a personal bond that remains intact even after they both returned to Kyrgyzstan. Back home, Aziz and Bakyt even transform their friendship into a business partnership: as they had planned it already during their common days in Moscow, they now want to open their own small restaurant in their native city of Osh.

Before this dream can turn into reality, however, Aziz leaves Osh again and heads towards southern China. He relocates to the city of Guangzhou, which based on China's 1978 reforms towards a more liberal economy, during the 1990s, began to emerge as one of the world's prime centres for the industrial manufacturing of consumer products (Ikels 1996; Mathews 2012, 76). There, Aziz attaches himself to the small community of Kyrgyz traders in that region and starts working as a translator, mostly for visiting Russian businessmen. Besides earning some of his first money, Aziz tries hard to expand his local network and establishes ties with various Chinese factory chiefs.

As compared to many other foreign businessmen, such as those African traders in Guangzhou who only speak English, French or Arabic (Yang 2012), Aziz's ability to 
easily communicate in Mandarin reduces his risk of being cheated across the language barrier. Beyond the pragmatic standpoint of fewer information loss during unmediated verbal interaction, Aziz's language skills as well increase his symbolic capital and prestige when facing Chinese business partners. This trust Aziz apparently manages to translate into quantifiable advantages, such as when he purchased technical equipment and furniture for his common café with Bakyt at a considerably lower price than he could have anywhere in Kyrgyzstan. After several such initial investments made Aziz's first stay in Guangzhou 'a successful one', in 2012, he returns home to Osh to join Bakyt in their final preparations towards opening their café.

As concerns this common business venture, it is important to note that aside from some unavoidable start-up financing, neither Aziz nor his friend Bakyt looked for a long-term involvement of their parents or other members of their kin groups. Both young males make it clear that this should be 'their own business' and that they would not want their relatives to interfere into this. Such aspirations can be interpreted as part of youth agency that longs for emancipation from kinship paternalism, and as a proof that a boy's transition to adulthood has been completed (see Kirmse 2013, 185). For Aziz, in order to claim such status change towards his parents and towards a future wife, there would be no more convincing argument than to become a potent breadwinner in the form of an internationally operating businessman. As regards his personal well-being, we can understand Aziz's actions as an attempt to balance his larger social connectedness, which means support and dependency from his relatives, with his opportunities for individual achievement. Here, the latter would equal the gratifying and empowering feeling to be in control of one's own life (see Jankowiak 2009). In Aziz's eyes, most symbolically, this would be reflected by him sitting at the head of a table in his own house and within a harmonious corefamily set-up.

So much for Aziz and his translocal livelihood in between Osh in Kyrgyzstan, Moscow and Guangzhou. Our next case study introduces Habiba, a Tajik girl for whose current livelihood the entwinement of Islam and collective prestige plays more of a role than money-making and proofs of adult masculinity.

\section{Habiba: From Dushanbe to Moscow to Cairo - 'Being A Good Muslim Daughter'}

Habiba is a teenage Tajik girl who was born in the country's capital Dushanbe. Her translocal livelihood spans in between Moscow in Russia, Egypt's capital Cairo and Dushanbe. The major focus of Habiba's case will be on the role of religion in a translocal family setting that transgresses national borders and cultural boundaries, including those defined by gender and age.

Unlike Aziz, Habiba moved from Dushanbe to Moscow as part of her family's labour migration. Habiba's father was 'driven' to Moscow by Tajikistan's dire economic situation in the early years following the civil war (1992-1997). His generation paved the way for currently about two million mostly young and middle-aged Tajik men and women abroad, whose remittances amount up to $35 \%$ of Tajikistan's GNP (making it the most remittance-dependent country in the world; Danzer and Ivaschenko 2010; Schmitz and Wolters 2012, 15). In Moscow, with support from his relatives in Dushanbe, Habiba's father managed to establish a successful trade business with pharmaceuticals from the Russian capital to Dushanbe. In parallel, 
Habiba's family started to live a mobile life with frequent trips in between these two cities.

Beyond their economic success, it has been the freedom to practice and express their Islamic belief for which Habiba's parents cherish Moscow. They contrast this with experiences from their native country Tajikistan. There the government's 'law on religion, ${ }^{, 7}$ aims to strictly control the religious associations and practices of the country's Sunni Muslim majority, suspecting any spirituality outside the state's secular paradigm of religious extremism that jeopardizes the fragile nation-state-building project (Epkenhans 2011). 'Although Russia is a non-Muslim state, Tajiks there can practice their religion freely', says Habiba's father. 'But here', he continues, 'in Tajikistan our Muslim government illegalizes public prayers and religious home education for our children'.

In Moscow's 'tolerant environment', however, Habiba's father and his wife experienced a spiritual reawakening, which brought them closer to a scriptural interpretation of Islam, as well as a to a publicly visible Islamic lifestyle that includes Islamic dress codes, regular mosque attendance and the hajj pilgrimage to Mecca. This new piety also accelerated the family's integration into the Muslim community of urban Moscow. In this diverse setting, Habiba's family could experience new forms of global belonging beyond the narrow regional and ethnic boundaries of Tajik society in the aftermath of civil war (McLoughlin 2010; Stephan 2006). From this influence, Habiba's parents also discovered new strategies for synchronizing their daughter's social upbringing with Islamic principles.

For Habiba herself, this has created a situation in which her parents' ambitions to make her a 'good Muslim daughter', and in consequence, a promising future bride for Dushanbe's marriage market, were opposed to her own aspirations of enjoying some 'regular' free-time leisures as any other 'modern youth' in Moscow. What Habiba would wish for in that regard is to join her urban friends - some of whom are ethnic Russians, while others are Tajiks - when they head over to a cinema or a shopping mall after school. Preferably, Habiba would do so in a 'European' style of dressing. Yet although she is generally allowed to socialize with her non-Tajik or non-Muslim peers, the newly developed religious attitudes of Habiba's parents, most symbolically, have materialized in the demand that their daughter wears a hijab.

Beyond the hijab, Habiba's parents wanted to continue on the long-standing practice within Muslim Tajik families to send teenage kids 'away' in order to guarantee their adequate religious education and traditional-moral upbringing while coming of age (Stephan 2010). In general, such 'sending away' might have meant that Habiba would spend some time in her parents' native village (in the northern mountainous region of Gharm) or that she would attend religious lessons in a neighbourhood mosque of Dushanbe.

In contrast to this, it resembles Habiba's parents' heightened religious aspirations that they wanted their daughter to be taught and instructed in what they call a 'truly Muslim country', such as Egypt. This reflects a widespread persuasion among Sunni Muslims from Central Asia that in terms of devotion and religious knowledge, both the local clerics and practitioners of their home region have not yet achieved the standards of 'authentic and pure Muslimness' as it is associated with Islam's historical centres in the Arab world and a more scriptural, 'non-traditional' Islam. ${ }^{8}$ With this inferior mind-set on the marginal position of post-Soviet 'traditional' and 'ignorant' Muslims, Habiba's parents decided that their daughter should get an Islamic education in a learning centre associated with Cairo's famous Al-Azhar University. 
So in 2010, Habiba leaves for Egypt, where for one year, she studies Arabic and is introduced to reciting the Koran.

Another translocal angle in Habiba's life relates to her home country Tajikistan. Whenever Habiba's family visits home (may that be Dushanbe or the parents' native village), this is a time of joyous reunifications with members of their extended family and kinship group. Yet at the same time, it is an inextricable part of these encounters to claim and negotiate social reputation, which in Habiba's case means that her family's development abroad is evaluated against the expectations of a (good) 'traditional' way of life. In Tajikistan, the emergence of mass labour migration to Russia has generated a public debate about the moral dangers of relocating to a non-Muslim country. The increase of divorce rates is attributed to such 'decline in values', 9 as is the erosion of the traditional intergenerational contract, which, for instance, expects the youngest son of a family to reside with his parents and care for them in their old age.

With this in mind, the major concern of her relatives in Tajikistan is that due to their long stay abroad, Habiba's family might be drifting towards a 'Western or European lifestyle' marked by moral decay and elaborate individuality. Most obviously, Habiba's parents have responded to this social pressure by closely connecting their family to the global ummah of believers and to a 'pure' Islam. Habiba's translocal Islamic education confirms a distinct 'religious conservatism', which, in a culturally diverse urban environment such as Moscow, ties migrants closer to their homeland and warrants cultural continuity (Van der Veer 2001, 9).

But at the same time, Habiba's 'pure' religious knowledge and her temporal proximity to one of the imagined learning centres of Islam (Al-Azhar in Cairo) have evidently increased her symbolic capital. Given that many contemporary Tajik Muslims aim for a connection to the wider Islamic world beyond the narrow confinements of their state-controlled religious environment in Tajikistan, the opportunities of Habiba's family to position her daughter beneficially in Dushanbe' marriage market are rather good. There she 'competes' with other young female Muslims, whose pious morality also has found its public expression in wearing the hijab and in other forms of global Islamic consumption and presentation (McBrien 2012; Pink 2009).

From Habiba's perspective, however, the religious and social ambitions of her parents limit her own freedom to explore youthfulness with her peers in a European surrounding. Within her translocal livelihood of divergent cultural locations Moscow's urban modernity, local traditions in Dushanbe and a 'pure' Arab Islam for Habiba, 'rebellious behaviour' has emerged as an effective strategy to pursue her own dreams against the expectations of her parents and relatives. By rejecting the hijab as 'ugly' (bezeb) and 'antiquated' (qadima), Habiba counters notions of female Muslim beauty and modernity that shape both Europe's and Central Asia's urban public (McBrien 2009; Ünal and Moors 2012). Furthermore, when Habiba qualifies Tajikistan as 'backward' (qafomonda) and 'uncivilized' (bemadaniyat), and depicts her relatives as 'boring' because 'they only go on about weddings and meals', she positions her original home as a 'cultural' and 'un-modern' adversary to Moscow's modern und free urban life. A line of conflict therefore emerges whenever Habiba should be presented as 'a good Muslim daughter'. Instead of going along with her parents for a visit to relatives or potential in-laws, Habiba oftentimes locks herself in a room of the family's apartment in Dushanbe to reconnect to her friends in Moscow via 'Skype'. 
Most of all, Habiba's case reveals how an elevated Muslim morality might both attenuate and elevate the tensions within a family livelihood in between modern Moscow's success and traditional Tajik collective expectations. At the opposite end of possibilities for a Central Asian female translocal figuration, we may find someone like Bermet: a young Kyrgyz woman, for whom professional success and individual freedom as a source of well-being originate in achieving a 'Western education'.

\section{Bermet: From Rural Issyk-Kul to Urban Bishkek - 'Education for Independence'}

The stories of Aziz, the emerging Central Asian trader, and Habiba, who is manoeuvring to be at the same time 'modern' and a 'good Muslim daughter', both cover long distances across multiple nation-state borders in between Kyrgyzstan, Tajikistan, Russia, Egypt and China. As such, Habiba's and Aziz's cases are paradigmatic instances of transnationalism, understood as referring 'to multiple ties and interactions linking people or institutions across the borders of nation-states' (Vertovec 1999, 447). With the following story of Bermet, however, we can illustrate one key reason why we prefer the term translocality over the term transnationalism.

Certainly, a glimpse into Bermet's lifeworld will confirm Appadurai's (1996, 5) insight that imagination has become 'a collective, social fact', meaning that localities may be charged and produced with significant amounts of transnational content 'from the outside' that is travelling with agents such as development workers, traders, the internet or other media. Beyond that, we can observe that translocal contexts as well are shaped by the particular ratio between such mediated imagination and a person's first-hand experiences. In cases, therefore, when the main actors of a lifeworld do not transgress national borders themselves, or when they lack own personal ties abroad, other boundaries than those pertaining to nation-states might prove essential. Later on, this will be discussed in regard to ethnic boundaries in a cross-border setting between Uzbekistan and Tajikistan. Now, and as far as Bermet is concerned, our primary attention is on educational opportunities in Kyrgyzstan, and on the multiple 'cultural separations' between urban and rural domains within this country.

Bermet was born in the middle of the 1980s in a small village close to Kyrgyzstan's Lake Issyk-Kul, about 250 kilometres east of the country's capital Bishkek. In many ways, Bermet had a 'typical' village childhood during the years of Soviet to postSoviet transformation. Through the difficult 1990s, she experienced the effects of her newly independent government's decisions to implement 'democratic reforms' and 'economic liberalization' (Abazov 1999). Especially in the beginning, this move away from socialism and a centralized command economy meant that state agencies were substantially less involved than before in the regulation of prices and the labour market, as well as in the health, transport and education sectors. With rising unemployment and lower salaries, with higher prices and less state provision, the growing hardships of village life led to high numbers of internal migrants who were heading towards the capital Bishkek (Kostyukova 1994). Bermet's family was not among those leaving for the city, primarily because both her parents could continue to work as teachers in the village school.

At the same time, Kyrgyzstan's particular post-Soviet pathway, which especially in comparison to its neighbours Uzbekistan and Tajikistan strongly embraced 'Western ideals', attracted all kinds of international NGOs and aid agencies with an 
agenda to promote civil society development (Kirmse 2013, 209-263; Pétric 2005). Bermet first entered into this system of outside-funded opportunities for Kyrgyzstan's next generation when she started attending the English lessons that a volunteer of the American 'Peace Corps' offered in her village. This decision reflects Bermet's early awareness, at about 14 years of age, that 'nothing else than education will spare me from a future in my village, from having to marry early, and from being no more than a house-wife'. Supported by her parents, who chose to maintain the 'Soviet accomplishment' of facilitating female education, Bermet studies hard and then actually 'wins' a rare spot in the scholarship program of Bishkek's 'American University of Central Asia' (Reeves 2004, 2005).

When in 2003, Bermet moves from her village to Bishkek to begin her studies, she crosses multiple boundaries, which since then have become parts of her particular translocal livelihood. An important such boundary is a linguistic one. Although Russian had been a continuous part of Bermet's school curriculum, her primary language of communicating within her (extended) family and with her friends always was Kyrgyz (a Turkic language). In Bishkek, however, Russian has been the lingua franca since Soviet times (Schröder 2012); and despite some recent legislative attempts to promote the status of Kyrgyz as the 'state language', Russian remains vital in business, popular culture and the media for conversations between different ethnic groups, same as for receiving a higher education. Therefore, as a student at the 'American University' and as a new inhabitant of Kyrgyzstan's capital, it was a crucial adaptation for Bermet to further improve both her English and her Russian. Aside from academic reasons, speaking 'proper Russian' was necessary for Bermet to socialize within her circles of urban peers, but also to embed herself in Bishkek's cultural fabric and to avoid being stigmatized as an 'uncivilized rural' (Alymbaeva 2013; Flynn and Kosmarskaya 2012; Schröder 2010, 2012).

After her university studies, Bermet's by now excellent English language skills enabled her to cross still further boundaries. Professionally, over the years, Bermet found different well-paid jobs in Bishkek, working for a Canadian-based gold mining company, for various international NGOs and for USAID-sponsored development projects. Alongside this job environment, Bermet enjoyed to be part of Bishkek's vibrant 'community' of international expatriates. There, she discovered new private interests (such as bowling or snow-boarding) and made new friends: local Kyrgyz ones with a shared affinity for a 'more Western, less traditional lifestyle', as well as foreigners who for some time were 'stationed' in Bishkek.

At this point, the entwinement of professional success, individual ambitions and collective cultural expectations within Bermet's livelihood in between localities - the past life in the village and the present life in the city - becomes obvious. Bermet's well-paid jobs with Western organizations turned her into a major breadwinner for her family, allowing her to compensate for the small salaries of her parents and to pay for her smallest brother's tuition fees.

Quite consciously, Bermet slips hints at the importance of her continued financial support into those 'arduous conversations', by which her relatives try to persuade her that she should marry soon, 'before ...', in her words, 'I get too old and cannot find anyone anymore'. In this way, Bermet utilizes the economic capital (into which she has transferred the cultural capital of her university degree) to manage what she calls a 'balance': between the responsibilities that she has accepted to take on towards her siblings or parents, and her personal well-being, which she expresses as having an 'exciting, free life in the city' and 'marrying someone I love and I choose'. 
In particular the latter perspective, which reflects the classic 'liberal arts' values of 'freedom', 'critical thinking' and 'individualism' that Bermet's university alma mater stands for, distinguishes her from both Aziz and Habiba. Unlike Aziz, who longs for quick success to become the head of a family, Bermet tries to use her leverage for delaying her dependency on a husband; and unlike Habiba, for whose family, social prestige emerges from Islamic purity, Bermet's reputation origins in professional skills measured in a salary.

Quite different from these cases is the following one of Bilal and Zebi: not only because they are a married couple and no youth anymore, but also because their story reveals how border-crossings in Central Asia's Fergana Valley may lead into a livelihood of simultaneous translocal 'cultural belonging' and ethnic marginalization.

\section{Bilal and Zebi: From Namangan in Uzbekistan to Urban Dushanbe in Tajikistan - 'Cultural Belonging and Ethnic Marginalization Across State Borders'}

The story of Bilal and Zebi began in 1992, a time when the fragile nationstate-building process in post-Soviet Tajikistan led into a bloody civil war that forced masses of people to leave their homes. ${ }^{11}$ Among these refugees were many Uzbeks, who as Tajikistan's largest national minority group, had become a main target of an aggressive civil war discourse that mobilized people for violence against the 'ethnic', 'regional' or 'religious'/'secular' Other (mahallgaroi).

Bilal, the son of a pious Muslim and Uzbek farmer was one of those who relocated to relatives in other countries to save their lives. Once the violence had reached his native village, $30 \mathrm{~km}$ east of Tajikistan's capital Dushanbe, he fled across the border to a small town in the Namangan region in Uzbekistan's part of the Fergana valley. This migration path had already been set up by Bilal's grandfather, an influential Islamic scholar, who in the 1920s fled Stalin's 'Kulak' purges from Namangan to the territory that later (1929-1991) should become the Soviet Socialist Republic of Tajikistan (see Emadi 1994).

Bilal was warmly welcomed in Namangan by his father's relatives. Later on, these relatives helped Bilal to arrange his marriage with Zebi, an Uzbek girl and close relative from a religiously educated family in this region. Although Zebi's family offered the newlyweds to stay and live with them, as soon as the civil war calmed down in 1997, Bilal took his wife back to Tajikistan, because: 'My home (vatan) is in Tajikistan, the place where I was born, where my parents live and where I will settle with my future family'. As the youngest son, the generational order assigned him this place 'at home', where he should care for and then inherit his fathers' house and land.

For Zebi, moving to a new place and her husband's 'home' marked a crucial transition in her life-cycle and confirmed her new status as a wife and daughter-in-law (kelin). Her post-marital relocation is not at all uncommon in this region, but rather bears witness to the well-established translocal marriage patterns of the ethnic Uzbek before, during and after the Soviet period (see Reeves 2007). In times of post-Soviet independent nation-states, for many Uzbeks this cross-border bride exchange opens up essential networks of mutual support, and also is a meaningful source to strengthen their cultural, economic, social and emotional bond with their historic 'Uzbek home' (see also Conradson and McKay 2007, 168-169). 
The first post-civil war years brought economic hardships for Bilal's extended family. When his father died in the early 2000s, Bilal took a momentous decision and handed over the land and courtyard to his older brother in order to move to Dushanbe with Zebi. This he did, because Bilal felt responsible for his older brother, who was traumatized by the Civil War and outside of farming had never learned any other craft. Bilal, on the other hand, had been trained as a metal worker in Dushanbe and so he seemed to be equipped with the professional skills to build a successful live in the city.

Another reason for Bilal's decision was that he cared for the well-being of his wife. Zebi had been socialized in the urban setting of an Uzbek regional city, which made it hard for her to navigate in the 'narrow' lifeworld of Bilal's Tajik village. In contrast to that Dushanbe's leisure and job opportunities attracted her much more and fuelled her desires. Thus, with the expectation for a 'good urban life', the family left Bilal's village to build a new 'home' in the city.

With financial support from Zebi's family in Uzbekistan, and with a loan from his father's relatives, Bilal bought a small hovli (a living unit that usually combines a single-storied house with an interior courtyard). Although it was a considerable investment for them, Zebi and Bilal imagined this hovli to become an important factor for their livelihood. For Zebi, living in a hovli within an urban surrounding and easy access to the city's infrastructure reproduced her natal family's lifestyle, and so was a highly affective link towards her birthplace. For Bilal, on the other hand, the courtyard was an opportunity to keep his rural identity as a farmer instead of having to transform into a full urbanite. Also, he used the yard as storage for the metal business that he tried to establish in this new neighbourhood. In the beginning, for Bilal and Zebi, their own hovli seemed as a first step in their successful integration in Dushanbe, while at the same time, they could maintain their emotional links to their different cultural urban or rural 'homes'.

Eventually, however, the family's new life in Dushanbe neither led to economic success, nor to their desired urban happiness. In a weak post-civil war economy, Bilal could not manage to find a stable job in the city, and so he worked for some time as a scrap metal dealer on a small Sunday bazaar. But Zebi and Bilal's precarious urban livelihood was not only caused by a general economic crisis. Their lack of social capital was revealed most strikingly when the couple celebrated their two sons' circumcision. Here, the fact that many of the expected guests, primarily Bilal's relatives and neighbours, did not come to their home exemplified their social isolation. Beyond that, it deprived Bilal and Zebi of the money gifts that usually are an essential part of this ritual economy.

In consequence, Bilal had to sell their hovli to pay back his debts and the family moved to another part of Dushanbe. This poorer neighbourhood was located in the city's outskirts and mostly was inhabited by civil war refugees from different regions of Tajikistan. In this neighbourhood, Bilal and Zebi's situation of feeling like 'strangers among strangers' was further aggravated by the violent rhetoric of mahallgaroi. Ever since Tajikistan's civil war, this discourse has furthered societal fragmentation along ethnic or regional lines, and remains a significant guide for many daily exchanges until today (Akbarzadeh 1996; Roche 2013). For Bilal and his family, as ethnic Uzbeks among Tajik neighbours from the northeast (Gharm region) or south of the Republic (Khatlon region), this has meant to be excluded from the neighbourhood's local ritual economy and other forms of mutual support. 
In such a 'quasi-diasporic context', which is shaped by the everyday politics of social inclusion and exclusion (Taylor 2013), their 'Uzbekness' became a crucial reference point for Bilal and Zebi. Drawing on their 'distinct Uzbek cultural and religious traditions', as well as on the 'civilizing and Islamizing merits' that are said to have been brought to Tajikistan by Uzbeks such as Bilal's grandfather, the couple expresses cultural, moral and religious superiority over their Tajik neighbours. Distinguishing themselves from 'the Tajiks of the mountains and desserts', who are 'without religious belief' (beiymon) and 'without good manners' (beodobu akhloq), Bilal and Zebi cultivate a 'homing desire' (McLoughlin 2010) that covers a highly moralized but also nostalgic evocation of social fairness, respectability and modesty. As a coping strategy, their 'homing desire' helps the family to stick together in times of uncertainty and crisis among ethnic strangers.

Belonging to a translocal, imagined Uzbek community ensures cultural continuity and emotional balance. At the same time, Bilal and Zebi have divergent associations with 'home' and a 'good life', which generally run along a rural vs. urban dichotomy. For Zebi, her previous home in Uzbekistan is a crucial source for urban lifestyle orientations. The food she prepares, her desire to decorate the house with contemporary designs and also her wish to become more pious and wear the hijab: all are influences that Zebi draws from the regular phone conversations with her sisters in Uzbekistan, from her visits to the Namangan region and from the Uzbek TV programmes she watches in Tajikistan. Her intimate and continuous exchanges with the relatives in Uzbekistan mark a core facet of Zebi's well-being, and cushion both her social isolation and her elusive desires in Dushanbe. In contrast, Bilal does not share his wife's interests in urban fashion and entertainment. For him, 'higher moral values', such as personal integrity, modesty and inner belief are important immaterial links tying him to the rural traditions of his pious family.

Finally, this complex range of urban challenges and ethnic intimacies aside, Bilal and Zebi's precarious translocal livelihood has been shaped as well by the 'greater games' between Tajikistan and Uzbekistan. Ever since in 1991, the demarcations between these neighbouring countries changed from All-Union Soviet borders to international ones between independent states, Zebi's cross-border mobility has depended on the regional political climate.

Here, within the last two decades, ethnonationalism as a 'source of statehood' (Heathershaw and Herzig 2011) has considerably played into Tajikistan's tensions with Uzbekistan. These are furthermore fuelled by conflicts over water resources or the dangers of insurgent Muslim militant movements. In between such continued state-interdependence and governmental attempts to secure territorial integrity, especially the borders in the Fergana Valley have become highly contested fields, with constraining consequences for the mobility of everyday actors (see Reeves 2014).

Drawing on Fumagalli's (2007, 105-106) observation that Uzbekistan's elites have not made significant efforts to develop links with their 'co-ethnics abroad', Liu $(2012,45)$ convincingly argues that Uzbeks living in southern Kyrgyzstan have been forced 'to think about their dilemmas through the prism of the border, as a space that concretizes their marginal status in both republics'. Apparently, this is true for Zebi as well, who states that border-crossings in between Tajikistan and Uzbekistan for her have become riskier, more bribe-intensive, stressful and time-consuming (see Reeves 2007). All of this discourages her from visiting her Namangan 'home' as frequently as before. 


\section{Social Hierarchies and Well-being}

At the beginning of this article, we argued for a conceptual expansion in two directions to be able to grasp the everyday small games that non-elite actors engage in within the 'New Great Game' of geostrategy and resource-competition in Central Asia.

Our first suggestion was to expand the notion of livelihood into realms beyond material necessities to include aspects such as social relatedness, subjective aspirations and emotions. This fits quite well with an emerging debate on the anthropological exploration of 'well-being', which Mathews and Izquierdo (2009a, 3) understand as 'being well' psychologically, physically, socioeconomically and culturally. Secondly, as regards the contexts in which our interlocutors dwell, we believe that 'translocal' is a better fit than 'transnational' in order to reflect also those transgressions where, for instance, cultural and linguistic boundaries may matter more than national borders. As obvious, these are arguments for subtle shifts, i.e. for adaptations in degrees and not in kind, as much did this combined notion of 'translocal livelihoods' help us in making sense of the case studies presented here.

Continuing on that, we now want to discuss how well-being may be assessed and narrated differently, depending on our interlocutors' presence in various localities, as well as depending on their positioning within traditional social hierarchies, especially those of gender and generation. This adds some further contextualization to the general insight that well-being oscillates between the personal wish for 'freedom from coercive control' and the embedding of actors in webs of social and emotional support (Mathews and Izquierdo 2009b, 254).

A vivid example of such diverging perspectives, which reveals lines of conflict and issues of power in shared translocal livelihoods, could be found in Habiba's case. Habiba's father appreciates Moscow's 'liberal climate' to practice his Muslim faith, and this piety (as symbolic capital) strengthens his social reputation to negotiate the family's moral and social standing both in Moscow and 'at home' in Tajikistan. Habiba, on the other hand, perceives her father's demands to wear the $h i$ $j a b$ not as a welcome protection against the uncertainties while coming of age in a contradictory world in between 'modern' urban Moscow and 'traditional' urban Tajikistan. To the contrary, because her exposure to Muslim faith is strongly determined by her parents, Habiba, unlike other young Muslim women in urban Moscow, cannot perceive religion as a source of agency or emancipation (see Sabirova 2011). Therefore, Habiba has experienced Islam primarily as an obstacle in her efforts to socialize with non-Muslim (Russian) peers and to develop an adolescent individual identity, where a 'European lifestyle' not at all contradicts 'being Tajik'. So far Habiba's only source for empowerment has been to subvert this parental dominance at times, such as when rejecting to wear the hijab in Moscow's or Dushanbe's public, or when she resists to join her parents on their visits to Dushanbe relatives.

At the same time, the extent of following along with such traditional orders apparently also depends on the location. Here, in all our cases, the 'home'-setting in Central Asia was experienced by our interlocutors as creating a maximum of social pressure to comply with collective, patriarchal expectations: e.g. for a female to prove to her (future) husband's kin that she would be a 'good' wife, or for men to become breadwinners, and to present their willingness to care for their ageing parents. This was well exemplified by Aziz's urgent wish to marry and have his own family soon after taking his first steps towards becoming a successful 'businessman'. 
For him, such upwards status change, from a son to a husband, would entail emancipation from his parents, also because Aziz expects his future wife to take on the major non-financial responsibilities of caring for her new in-laws $(k u d a)$.

In this regard, the case of Bilal and Zebi offered some insights on how trying to leave such cultural expectations behind may lead to social marginalization. Their move from Bilal's home village, where he was supposed to take over his father's hovli, to Dushanbe, where his wife felt less bounded and 'closer' to her own urban roots, eventually lead to a situation when none of his relatives attended their son's circumcision party.

Bilal's and Zebi's aspiration, that geographic mobility into a 'foreign' urban context furthers social mobility, could as well be found in the other three case studies: be that Aziz and Habiba's father, who first had relocated from southern Kyrgyzstan or central Tajikistan to Moscow, or Bermet, who within Kyrgyzstan moved to Bishkek in order to study. A further commonality here is that, regardless of the terms they used - uspeh in Russian, iygilik in Kyrgyz or barakat in Tajik - our interlocutors understood success 'first of all' to manifest as money income.

In their view, such material success can then translate into other forms of personal well-being. This was quite clearly illustrated in the case of Bermet, who admits to use her well-paid job with an international NGO as leverage for individual freedom within her kinship relations in order to delay her marriage, and in the future be able to choose a husband to her own liking. But also in the case of Habiba's father, we could see that well-being means integrating worldly achievements with after-worldly orientations. Besides economic success with his pharmaceuticals business, for him a 'good life' (zindagii khub) entailed a 'religious career', as part of which he sponsored his daughter's Islamic education while he himself became a hajji.

Related to well-being and mobility, our interlocutors associate the foreign urban locale of their translocal livelihoods with more freedom, most importantly from pressures to convey with the cultural regimes of their Central Asian home. Aside from the ones already mentioned, this includes regular contributions to weddings, circumcision celebrations or other religious and kinship rituals. Distancing oneself (or one's family) just enough from such expectations oftentimes transforms into a balancing act, in which migration towards new urban opportunities continuously has to be presented as a 'success story' to those who stay behind. On the other hand, when such distancing from norm-compliance and participation in collective rituals meets with economic failure, this may risk someone's inclusion in kinship or other informal support systems. This again may turn into a rather serious concern when taking into account that in none of the Central Asian states, there exist elaborate state-sponsored safety nets with pension funds, health care or unemployment benefits.

While Bermet succeeds in this balancing act with the help of her good job, for Aziz, it has remained a future aspiration, which he will have to delay until after his first successes as a businessman and his marriage. The case of a failing balancing act seems to be that of Bilal and Zebi's, whose relocation to the city did not only mean economic struggles, but also marginalized them within their kinship group. In reaction to that, they are nursing a 'homing desire' for a cross-border Uzbek ethnic community. Most strikingly, this is expressed by Zebi, who projects all her positive emotions of 'a better life' onto her Namangan home region.

And still, the single locales within these translocal livelihoods are not too neatly compartmentalized, but remain ambivalent. ${ }^{12}$ Here, the foreign urban place is not only freedom and economic success, but also means dealing with risks, such as 
strong job competition, language barriers and, especially in the case of Moscow, anti-migrant xenophobia (see Reeves 2013, 321). In the same way, for our interlocutors, the rural areas of Central Asia are not unequivocally associated with cultural pressures from hierarchies of gender and generation. As an 'ancestral home', these settings as well are sources of well-being in terms of childhood memories, social relatedness, imaginations of a glorious future return and an unchallenged belonging.

\section{Conclusion}

This article examined both material and intangible aspects of livelihoods that span between the 'homes' of our Central Asian interlocutors and cities in Russia, Egypt and China. Our ethnographic case studies touched on everyday economies and social networking, religious convictions and youth lifestyles, education and ethnicity to illustrate how translocal contexts evolve from both practices of place-making as well as from transgressions of national borders, linguistic, cultural and geographic boundaries.

In the previous section, we then elaborated further on the 'institutionalization of mobility', discussing how the connections between our interlocutors' personal wellbeing and their inclusion in social hierarchies of generation and gender play out in different locales and their histories. Here, the ethnic Kyrgyz, Tajik and Uzbek migrants of our cases expressed simultaneous belonging to their 'native lands' in Central Asia and to their newer places of residence abroad. But also, there emerged an ambivalent picture, in which the Central Asian 'home' is presented as a setting of both intimacy and strong expectations for norm-compliance, while the migration destinations may promise success and freedom, yet not without the price of detachment and uncertainty.

Aiming at illustration and exploration instead of representation, our case studies only give early insights into what translocal livelihoods of Central Asians hold in store. Within the last two decades, these livelihoods have displayed a particular expansion. In the Soviet Union, a private business-orientation towards China, such as that of Aziz's, would have been in deep conflict with Socialist ideology. At that time, this would have been as unattainable as the wish of non-elite Tajiks for a stronger attachment to the wider Muslim world in the Near East (Habiba's father), or the realization of education and job opportunities that currently are sponsored by the presence of 'Western' aid-agencies in Central Asia (Bermet). Although for some, the post-Soviet period meant a contraction of their livelihood, for example, through the installation of new, international border regimes (Bilal and Zebi), our interlocutors generally express satisfaction and relief to have more control over their movements, orientations and choices than in the previous communist era (see Jankowiak 2009, 162).

From that perspective, our article explored contemporary translocal livelihoods of mobile actors to offer insights on how their recurring motions of leaving (behind), living (abroad) and returning (home) are tied to social and material exchanges, and emotional geographies. For future research, to learn more about notions and 'negotiations of well-being' among Central Asians, (Montgomery 2013, 428-429) seems to be a promising way forward. As we have argued here, the practices and elements associated with well-being should as well be followed up along the actors' relations that lead outside of a fixed 'nation-state' or 'area' setting (such as that of the postSoviet world's). 
Within such translocal contexts, well-being is shaped in particular ways by experiences of mobility and its institutionalizations. Here, however, gender and generation are only two aspects that may become relevant when actors in different social positionings negotiate well-being. A possible theme for future research on the translocal livelihoods of Central Asians therefore emerges from the multiple intersections of mobility and well-being with particular notions of time and turning points in individual life courses. For example, this may then concern such cases when the practice of travelling itself is understood as an integral 'rites de passage' within an individual biography (Monsutti 2007). In that regard, some ethnic groups of Central Asia could draw on their pre-Soviet identities to frame their present mobilities as a resilient continuation of their 'rich nomadic heritage'.

\section{Acknowledgements}

This work is part of the research project 'Translocal Goods - Education, Work, and Commodities between Tajikistan, Kyrgyzstan, Russia, China, and the Arab Emirates' [grant number: Az. 86870], which has been funded by the VolkswagenStiftung (Volkswagen Foundation) since May 2013 (http://iaaw.hu-berlin.de/islam/translocalgoods).

\section{Notes}

1. Unlike, for instance, Canfield and Rasuly-Paleczek (2011), in this article we do not aim to look at 'Greater Central Asia', which is then understood to include the South Caucasus, China's Xinjiang province, Afghanistan, Pakistan, Iran and Turkey. Instead, we refer to Central Asia as the postSoviet countries Tajikistan, Kyrgyzstan, Kazakhstan, Uzbekistan and Turkmenistan.

2. For an earlier exception, see Atabaki and Mehendale 2005.

3. Beyond Smith's (2011) intention to distinguish his own understanding of translocality from those of Appadurai's (1996) and Hannerz's (1998), still the closeness and interplay between the terms transnational and translocal can be extracted from the following quote $(2011,181)$ : 'Put simply, my take on transnationalism and the city focuses on the socio-spatial processes by which social actors and their networks forge translocal connections and create the linkages between and across places that I called translocality'.

4. Therefore, when explicitly aiming to 'de-naturalize the national in research methodologies', one might as well think about labelling this not as 'methodological transnationalism' (Amelina and Faist 2012), but as methodological translocalism. See also Conradson and McKay's $(2007,169)$ take on this regarding the interplay of mobility, connection and emotion: 'At the level of everyday experience, we believe it thus makes as much sense to think of trans-local as trans-national subjectivities' [italics in original].

5. More specifically, Thieme's aim is to utilize Bourdieu's (1977) 'Theory of Practice' to address an 'under-theorization' that she diagnoses for both the field of transnational migration and livelihood studies. While certainly this is an intriguing thought for future theoretical debates, one which has also been brought up by Kokot (2009) for the study of 'success' in Armenian and other diaspora groups, in this article, our focus lies with the idea of livelihood.

6. See: http://news.namba.kg/read.php?id=1998391 (accessed 13 December 2013).

7. Tajikistan's 'law on religion' and its recent amplifications encompass the 'Law on Traditions, Festivities and Ceremonies' of 2007, the 'Law on Freedom of Consciousness and Religious Associations' of 2009 or of 2010, the law 'Concerned Parents', which deals with the responsibility for the social upbringing of children.

8. Due to their pervasive language reforms and anti-religious policies, over several decades, the Soviet Union had successfully isolated Tajik and other Central Asian Muslims from the flow of ideas, people and knowledge in the wider Muslim world. In this way, Islam became a localized 'frozen tradition', and as such, turned into an integral part of the cultural heritage of the Soviet Tajik nation (Saroyan 1997). 
9. See for instance http://www.rferl.org/content/SMS_Divorces_Cut_Tajik/1896511.html (accessed 17 December 2013).

10. See Schröder (2013) for a more elaborate discussion on the intertwinement of geographic and social mobility in the case of another young Kyrgyz woman. See Kirmse $(2013,184)$ for a similar case of a young Kyrgyz male.

11. While an estimated more than 1.2 million people became internally displaced persons in Tajikistan, a majority of refugees fled to neighbouring Afghanistan, Kyrgyzstan and Uzbekistan. See http://www.un.org/events/tenstories/06/story.asp?storyID=600 (accessed 17 December 2013).

12. In his examination of ethnic Uzbeks in the southern Kyrgyz city of Osh, Liu (2012) nicely illustrates how such ambivalence is produced from a combination of social relations, space and 'embodied presencing' $(2012,135)$ taking the classic mahalla neighbourhood setting: 'The strong link that narrators made between the mahalla and the cultivation of good persons was notably premised on the spatial qualities of the neighborhoods that somehow enabled this form of social life. The narrow, intimate qualities of the streets made for constant proximity and mutual involvement that promoted the enforcement of communal standards of behaviour and sentiment, whether regarded as good or oppressive'. $(2012,124)$.

\section{References}

Abazov, R. 1999. "Economic Migration in Post-Soviet Central Asia: The Case of Kyrgyzstan." PostCommunist Economies 11 (2): 237-252. doi:10.1080/14631379996002.

Ahrari, M. E. 2002. The New Great Game in Muslim Central Asia. Honolulu, HI: University Press of the Pacific.

Akbarzadeh, S. 1996. "Why did nationalism fail in Tajikistan?” Europe-Asia Studies 48 (7): 1105-1129.

Alymbaeva, A. A. 2013. "Internal Migration in Kyrgyzstan: A Geographical and Sociological Study of Rural Migration." In Migration and Social Upheaval in the Face of Globalization in Central Asia, edited by M. Laruelle, 117-148. Leiden: Brill.

Amelina, A., and T. Faist. 2012. "De-naturalizing the National in Research Methodologies: Key Concepts of Transnational Studies in Migration." Ethnic and Racial Studies 35 (10): 1707-1724. doi:10.1080/01419870.2012.659273.

Appadurai, A. 1996. Modernity at Large: Cultural Dimensions of Globalization. Minneapolis, MN: University of Minnesota Press.

Atabaki, T., and S. Mehendale, eds. 2005. Central Asia and the Caucasus. Transnationalism and the Diaspora. London: Routledge.

Basch, L. G., N. Glick Schiller, and C. S. Blanc. 1994. Nations Unbound: Transnational Projects, Postcolonial Predicaments, and Deterritorialized Nation-states. New York: Gordon and Breach.

Bourdieu, P. 1977. Outline of a Theory of Practice. Cambridge: Cambridge University Press.

Canfield, R. L., and G. Rasuly-Paleczek, eds. 2011. Ethnicity, Authority and Power in Central Asia. New Games Great and Small. London: Routledge.

Coleman, S., and P. von Hellermann, eds. 2011. Multi-sited Ethnography. Problems and Possibilities in the Translocation of Research Methods. New York: Routledge.

Conradson, D., and D. Mckay. 2007. “Translocal Subjectivities: Mobility, Connection, Emotion.” Mobilities 2 (2): 167-174. doi:10.1080/17450100701381524.

Cooley, A. 2012. Great Games, Local Rules: The New Great Power Contest in Central Asia. Oxford: Oxford University Press.

Danzer, A. M., and O. Ivaschenko. 2010. "Migration Patterns in a Remittances Dependent Economy. Evidence from Tajikistan during the Global Financial Crisis." Migration Letters 7 (2): 190-202. http://siteresources.worldbank.org/INTGENDER/Resources/336003-1250632365376/Tajikistan_AD OI_pdf.

Drotbohm, H. 2010. "Gossip and Social Control across the Seas: Targeting Gender, Resource Inequalities and Support in Cape Verdean Transnational Families." African and Black Diaspora: An International Journal 3 (1): 51-68. doi:10.1080/17528630903319839.

Edwards, M. 2003. "The New Great Game and the New Great Gamers: Disciples of Kipling and Mackinder." Central Asian Survey 22 (1): 83-102. doi:10.1080/0263493032000108644.

Emadi, H. 1994. "State, Ideology and Islamic Resurgence in Tadjikistan." Central Asian Survey 13 (4): 565-573. doi:10.1080/02634939408400883. 


\section{P. Schröder \& M. Stephan-Emmrich}

Engvall, J. 2011. "The State as Investment Market. An Analytical Framework for Interpreting Politics and Bureaucracy in Kyrgyzstan." PhD diss., Uppsala University. http://www.ucrs.uu.se/digitalAs sets/86/86335_JohanEngvallPhDDissertation.pdf.

Epkenhans, T. 2011. "Islam in the Security Discourse of the Post-Soviet Republics of Central Asia." In OSCE Yearbook 2010, edited by Institute for Peace Research and Security Policy, 93-103. BadenBaden: Nomos. http://www.core-hamburg.de/documents/yearbook/english/10/Epkenhans-en.pdf.

Ferguson, J. 2011. "Novelty and Method. Reflections on Global Fieldwork." In Multi-sited Ethnography. Problems and Possibilities in the Translocation of Research Methods, edited by S. Coleman and P. von Hellermann, 197-207. New York: Routledge.

Flynn, M., and N. Kosmarskaya. 2012. "Exploring 'North' and 'South' in Post-Soviet Bishkek: Discourses and Perceptions of Rural-Urban Migration.” Nationalities Papers 40 (3): 453-471. doi:10.1080/00905992.2012.685061.

Freitag, U., and A. von Oppen, eds. 2010. Translocality. The Study of Globalising Processes from a Southern Perspective. Leiden: Brill. http://public.eblib.com/EBLPublic/PublicView.do?ptiID= 634869.

Fumagalli, M. 2007. "Ethnicity, State Formation and Foreign Policy: Uzbekistan and 'Uzbeks Abroad'." Central Asian Survey 26 (1): 105-122. doi:10.1080/02634930701423525.

Glick Schiller, N. 2005. "Blood and Belonging: Long-distance Nationalism and the World beyond." In Complexities: Beyond Nature \& Nurture, edited by S. McKinnon and S. Silverman, 289-312. Chicago: University of Chicago Press.

Glick Schiller, N., and G. E. Fouron. 1999. "Terrains of Blood and Nation: Haitian Transnational Social Fields.” Ethnic and Racial Studies 22 (2): 340-366. doi:10.1080/014198799329512.

Glick Schiller, N., and A. Simsek-Caglar. 2009. Locating Migration: Rescaling Cities and Migrants. Ithaca: Cornell University Press.

Hannerz, U. 1996. Transnational Connections: Culture, People, Places. London: Routledge.

Hannerz, U. 1998. "Transnational Research." In Handbook of Methods in Cultural Anthropology, edited by H. R. Bernard, 235-256. Walnut Creek, CA: Alta Mira Press.

Heathershaw, J., and E. Herzig. 2011. "Introduction: The Sources of Statehood in Tajikistan." Central Asian Survey 30 (1): 5-19. doi:10.1080/02634937.2011.554049.

Hegland, M. E. 2010. "Tajik Male Labour Migration and Women Left behind: Can They Resist Gender and Generational Hierarchies?" Anthropology of the Middle East 5 (2): 16-35. doi:10.3167/ ame.2010.050203.

Heintze, B. 2010. "Translocal 'Kinship' Relations in Central African Politics of the 19th Century." In Translocality. The Study of Globalising Processes from a Southern Perspective, edited by U. Freitag and A. von Oppen, 179-206. Leiden: Brill. http://public.eblib.com/EBLPublic/PublicView.do? ptiID $=634869$.

Humphrey, C. 2002. The Unmaking of Soviet Life. Everyday Economies after Socialism. Ithaca: Cornell University Press.

Ikels, C. 1996. The Return of the God of Wealth: The Transition to a Market Economy in Urban China. Stanford: Stanford University Press.

Ingold, T. 2000. The Perception of the Environment: Essays on Livelihood, Dwelling \& Skill. London: Routledge.

Isabaeva, E. 2011. "Leaving to Enable Others to Remain: Remittances and New Moral Economies of Migration in Southern Kyrgyzstan." Central Asian Survey 30 (3-4): 541-554. doi:10.1080/ 02634937.2011 .607917$.

Jankowiak, W. 2009. "Well-being, Cultural Pathology, and Personal Rejuvenation in a Chinese City, 1981-2005." In Pursuits of Happiness. Well-being in Anthropological Perspective, edited by G. Mathews and C. Izquierdo, 147-166. New York: Berghahn Books.

Karrar, H. H. 2009. The New Silk Road Diplomacy: China's Central Asian Foreign Policy since the Cold War. Vancouver: UBC Press.

Kirmse, S. B. 2013. Youth and Globalization in Central Asia. Everyday Life between Religion, Media, and International Donors. Frankfurt/Main: Campus Verlag.

Kokot, W. 2009. "Diaspora as a Resource? Managing Social Capital in the Armenian Community of Sofia, Bulgaria." In Networks, Resources and Economic Action. Ethnographic Case Studies in Honor of Hartmut Lang, edited by W. Kokot and C. Greiner, 127-150. Berlin: Reimer.

Kostyukova, I. 1994. "The Towns of Kyrgyzstan Change Their Faces: Rural-Urban Migrants in Bishkek." Central Asian Survey 13 (3): 425-434. 
Lachenmann, G. 2010. "Globalization in the Making: Translocal Gendered Spaces in Muslim Societies." In Translocality. The Study of Globalising Processes from a Southern Perspective, edited by U. Freitag and A. von Oppen, 335-368. Leiden: Brill. http://public.eblib.com/EBLPublic/Public View.do?ptiID $=634869$.

Laruelle, M. 2007. “Central Asian Labor Migrants in Russia: The 'Diasporization' of the Central Asian States?" China and Eurasia Forum Quarterly 5 (3): 101-119.

Levitt, P., and N. Glick Schiller. 2004. "Conceptualizing Simultaneity: A Transnational Social Field Perspective on Society." International Migration Review 38 (3): 1002-1039. doi:10.1111/j.17477379.2004.tb00227.x.

Liu, M. Y. 2012. Under Solomon's Throne: Uzbek Visions of Renewal in Osh. Pittsburgh, PA: University of Pittsburgh Press.

Marcus, G. E. 1995. "Ethnography in/of the World System: The Emergence of Multi-sited Ethnography." Annual Review of Anthropology 24 (1): 95-117. doi:10.1146/annurev.an.24.100195.000523.

Mathews, G. 2012. "Neoliberalism and Globalization from below in Chungking Mansion, Hong Kong." In Globalization from below. The World's Other Economy, edited by G. Mathews, C. A. Vega, and G. L. Ribeiro, 69-85. New York: Routledge.

Mathews, G., and C. Izquierdo, eds. 2009a. Pursuits of Happiness. Well-being in Anthropological Perspective. New York: Berghahn Books.

Mathews, G., and C. Izquierdo. 2009b. "Conclusion. Towards an Anthropology of Well-being." In Pursuits of Happiness. Well-being in Anthropological Perspective, edited by G. Mathews and C. Izquierdo, 248-266. New York: Berghahn Books.

McBrien, J. 2009. "Mukadas's Struggle: Veils and Modernity in Kyrgyzstan." Journal of the Royal Anthropological Institute 15: 127-144. doi:10.1111/j.1467-9655.2009.01546.x.

McBrien, J. 2012. "Watching 'Clone': Brazilian Soap Operas and Muslimness in Kyrgyzstan.” Material Religion: The Journal of Objects, Art and Belief 8 (3): 374-396. doi:10.2752/ 175183412 X13415044208952.

Mckay, D. 2007. “'Sending Dollars Shows Feeling' - Emotions and Economies in Filipino Migration." Mobilities 2 (2): 175-194. doi:10.1080/17450100701381532.

McLoughlin, S. 2010. "Muslim Travellers Homing Desire, the Umma and British Pakistanis." In Diasporas: Concepts, Intersections, Identities, edited by K. Knott and S. McLoughlin, 223-229. London: Zed Books.

Melet, Y. 1998. "China's Political and Economic Relations with Kazakhstan and Kyrgyzstan.” Central Asian Survey 17 (2): 229-252. doi:10.1080/02634939808401035.

Monsutti, A. 2007. "Migration as a Rite of Passage: Young Afghans Building Masculinity and Adulthood in Iran." Iranian Studies 40 (2): 167-185.

Montgomery, D. W. 2013. "Negotiating Well-being in Central Asia." Central Asian Survey 32 (4): 423431. doi:10.1080/02634937.2013.871442.

Mullerson, R. A. 2007. Central Asia: A Chessboard and Player in the New Great Game. London: Kegan Paul.

Nieswand, B. 2011. Theorising Transnational Migration: The Status Paradox of Migration. London: Routledge.

Peleikis, A. 2010. "Heritage and the Making of (Trans-)Local Identities: A Case Study from the Curonian Spit (Lithuania)." In Translocality. The Study of Globalising Processes from a Southern Perspective, edited by U. Freitag and A. von Oppen, 229-248. Leiden: Brill. http://public.eblib.com/ EBLPublic/PublicView.do?ptiID=634869.

Pétric, B.-M. 2005. "Post-Soviet Kyrgyzstan or the Birth of a Globalized Protectorate." Centralcole Asian Survey 24 (3): 319-332. doi:10.1080/02634930500310402.

Pink, J., ed. 2009. Muslim Societies in the Age of Mass Consumption: Politics, Culture and Identity between the Local and the Global. Newcastle upon Tyne: Cambridge Scholars Publishing.

Pries, L. 2001. "The Approach of Transnational Spaces: Responding to New Configurations of the Social and the Spatial." In New Transnational Social Spaces: International Migration and Transnational Companies in the Early Twenty-first Century, edited by L. Pries, 3-33. London: Routledge.

Rashid, A. 2000. Taliban: Islam, Oil and the New Great Game in Central Asia. London: I.B. Tauris.

Reeves, M. 2004. "Cultivating 'Citizens of a New Type'. The Politics and Practice of Educational Reform at the American University in Kyrgyzstan." In The Challenges of Education in Central Asia, edited by S. P. Heyneman and A. J. De Young, 365-385. Greenwich, CT: Information Age. 


\section{P. Schröder \& M. Stephan-Emmrich}

Reeves, M. 2005. “Of Credits, Kontrakty and Critical Thinking: Encountering 'Market Reforms' in Kyrgyzstani Higher Education.” European Educational Research Journal 4 (1): 5-21. doi:10.2304/ eerj.2005.4.1.4.

Reeves, M. 2007. "Travels in the Margins of the State: Everyday Geography in the Ferghana Valley Borderlands." In Everyday Life in Central Asia: Past and Present, edited by J. Sahadeo and R. Zanca, 281-300. Bloomington: Indiana University Press.

Reeves, M. 2009. "Beyond Economic Determinism: Microdynamics of Migration from Rural Kyrgyzstan [in Russian].” Neprikosnovennyi Zapas 66 (4): 262-280.

Reeves, M. 2011. "Staying Put? Towards a Relational Politics of Mobility at a Time of Migration." Central Asian Survey 30 (3-4): 555-576. doi:10.1080/02634937.2011.614402.

Reeves, M. 2012. "Black Work, Green Money: Remittances, Ritual, and Domestic Economies in Southern Kyrgyzstan.” Slavic Review 71 (1): 108-134. doi:10.5612/slavicreview.71.1.0108.

Reeves, M. 2013. "Migration, Masculinity, and Transformations of Social Space in the Sokh Valley, Uzbekistan." In Migration and Social Upheaval as the Face of Globalization in Central Asia, edited by M. Laruelle, 307-331. Boston, MA: Brill.

Reeves, M. 2014. Border Work: Spatial Lives of the State in Rural Central Asia. Ithaca: Cornell University Press.

Roche, S. 2013. "Continuities and Disruptions in Islamic Education. Biographies of Shogirds in Tajikistan." In Anthropology of the Contemporary Middle East and Central Eurasia, edited by P. Khosronejad, 23-53. Canon Pyon: Sean Kingston.

Ruget, V., and B. Usmanalieva. 2008. "Citizenship, Migration and Loyalty towards the State: A Case Study of the Kyrgyzstani Migrants Working in Russia and Kazakhstan." Central Asian Survey 27 (2): 129-141. doi:10.1080/02634930802355055.

Sabirova, G. 2011. "Young Muslim-Tatar Girls of the Big City: Narrative Identities and Discourses on Islam in Postsoviet Russia." Religion, State and Society 39 (2-3): 327-345. doi:10.1080/ 09637494.2011.584710.

Sahadeo, J. 2011. "The Accidental Traders: Marginalization and Opportunity from the Southern Republics to Late Soviet Moscow." Central Asian Survey 30 (3-4): 521-540. doi:10.1080/ 02634937.2011 .602563 .

Saroyan, M. 1997. Minorities, Mullahs, and Modernity: Reshaping Community in the Former Soviet Union. Berkeley: University of California.

Schetter, C. 2012. "Translocal Lives. Patterns of Migration in Afghanistan.” Crossroads Asia Working Paper Series. http://crossroads-asia.de/fileadmin/user_upload/publications/deliverables/Con rad Schetter - Translocal Lives. Patterns of Migration in Afghanistan.pdf.

Schmitz, A., and A. Wolters. 2012. "Political Protest in Central Asia Potentials and Dynamics." SWP Research Paper Berlin. http://www.swp-berlin.org/fileadmin/contents/products/research_papers/ 2012_RP07_smz_wolters.pdf.

Schröder, P. 2010. "'Urbanizing' Bishkek: Interrelations of Boundaries, Migration, Group Size and Opportunity Structure." Central Asian Survey 29 (4): 453-467. doi:10.1080/ 02634937.2010 .537143 .

Schröder, P. 2012. From Shanghai to Iug-2: Integration and Identification among and beyond the Male Youth of a Bishkek Neighbourhood. PhD diss., Martin-Luther-Universität Halle-Wittenberg.

Schröder, P. 2013. "Ainuras Amerikanische Karriere. Räumliche Und Soziale Mobilität Einer Jungen Kirgisin." [Ainura's US-Career - The Spatial and Social Mobility of a Young Kyrgyz Woman.] Zeitschrift Für Ethnologie 138: 235-258.

Smith, M. P. 2011. “Translocality. A Critical Reflection.” In Translocal Geographies: Spaces, Places, Connections, edited by K. Brickell and A. Datta, 181-198. Burlington, VT: Ashgate.

Sorensen, N. N., and K. F. Olwig. 2002. Work and Migration: Life and Livelihoods in a Globalizing World. London: Routledge.

Stephan, M. 2006. "“You Come to Us like a Black Cloud': Universal versus Local Islam in Tajikistan." In The Postsocialist Religious Question: Faith and Power in Central Asia and East-Central Europe, edited by C. Hann and Civil Religion Group, 147-167. Münster: LIT-Verlag.

Stephan, M. 2010. "Education, Youth and Islam: The Growing Popularity of Private Religious Lessons in Dushanbe, Tajikistan." Central Asian Survey 29 (4): 469-483. doi:10.1080/ 02634937.2010 .538283 .

Tang, S. 2000. "Economic Integration in Central Asia: The Russian and Chinese Relationship." Asian Survey 40 (2): 360-376. doi:10.2307/3021137. 
Taylor, S. 2013. "'Home is Never Fully Achieved ... Even When We Are in It': Migration, Belonging and Social Exclusion within Punjabi Transnational Mobility." Mobilities 1-18. doi:10.1080/ 17450101.2013 .848606$.

Thieme, S. 2008. "Sustaining Livelihoods in Multi-local Settings: Possible Theoretical Linkages between Transnational Migration and Livelihood Studies." Mobilities 3 (1): 51-71. doi:10.1080/ 17450100701797315.

Ünal, R. A., and A. Moors. 2012. "Formats, Fabrics, and Fashions: Muslim Headscarves Revisited." Material Religion 8 (3): 308-329. doi:10.2752/175183412X13415044208835.

Van der Veer P. 2001. "Transnational Religion." WPTC-01-18 Paper, Presented at the Conference on Transnational Migration: Comparative Perspectives. Princeton, 30 June-1 July. http://www.xtome. org/docs/countries/india/WPTC-01-18\%20Van\%20der\%20Veer.pdf.

Velayutham, S., and A. Wise. 2005. "Moral Economies of a Translocal Village: Obligation and Shame among South Indian Transnational Migrants." Global Networks 5 (1): 27-47. doi:10.1111/j.14710374.2005.00106.x.

Vertovec, S. 1999. "Conceiving and Researching Transnationalism.” Ethnic and Racial Studies 22 (2): 447-462. doi:10.1080/014198799329558.

Vertovec, S. 2009. Transnationalism. London: Routledge.

Wimmer, A., and N. Glick Schiller. 2002. "Methodological Nationalism and Beyond: Nation-state Building, Migration and the Social Sciences." Global Networks 2 (4): 301-334. doi:10.1111/14710374.00043.

Yang, Y. 2012. “African Traders in Guangzhou Routes, Reasons, Profits, Dreams.” In Globalization from Below. The World's Other Economy, edited by G. Mathews, C. A. Vega, and G. L. Ribeiro, 154170. New York: Routledge. 